\title{
第84回日本内科学会講演会 (1987年)
}

\section{教 育 講 演 \\ 内科学の進歩 筋萎縮性側索硬化症* 東京医科娒科大学医学部神経内科塚越 廣}

\section{1. 筋萎縮性側索硬化症の定義と分類}

筋萎縮性側索硬化症 (以下ALS) は主として運 動ニューロンを侵す進行性変性疾患で, 同様な病 気に资髄性進行性筋萎縮症 (以下SMA) 之進行性 球麻㽻がある。病理的にALSは錐体路を含む上位 運動ニューロンと矢䯣・脳幹部運動細胞以下の下 位運動ニューロンを侵し, SMAと進行性球麻痹は 下位運動ニューロンのみを侵すとされる。しかし 臨床的にBabinski徵候陽性, 深部反射六進などの 錐体路徵候があっても，病理的に錐体路障害の明 らかでない例があり，錐体路徵候がなくとも病理 的に錐体路障害を認める例があって,これらの間 に明確な区別はなく、現在ではALSはSMA, 進行 性球麻痺を含屯と考えられる。今回は信州大第三 内科，東京医科歯科大神経内科の症例を主とし， 一部東大第三内科, 東大神経内科の経験例を加え た108例について述べる。臨床的に経過の短い ALS95例，経過が長く良性のSMA 13例を分け， ALS と同様な経過をとる進行性球麻疸はALS中 に含めた. ALS, SMAは家族性のあることがある が，家族性SMAは極めて多様で, ALSを中心に述 ベる時はこれを除外することがあり，今回も省略 乙て孤発性ALS とSMA, 家族性ALSについて述 ベる.

\section{2. 筋萎縮の初発部位, 分布, 脊㵦前角 運動神経細胞との関連}

筋萎縮の初発部位は上肢筋 31 例 $28.7 \%$, 下肢筋
38 例 $35.2 \%$, 球筋 30 例 $27.8 \%$ とほ心゙同数で, 下肢 筋が最も多く，その他全身筋，頝筋，呼吸筋初発 例が合わせて 9 例 $8.3 \%$ であった。これらは初発障 害部位を示し、上肢は䅡髄，下肢は腰䯣，球筋は 延髄に始まると考光られ，一般には上肢初発例が 多いとされている。上肢では遠位笳初発19例，近 位筋12例，下肢では遠位筋に始まり早期にアキレ 又反射消失を示す仮性多発神経炎型が16例，乙の 他の筋に始まるものが22例であった。

筋萎縮の分布は非対称性を示するのが82例76\% と多く，その中 62 例は上肢または下肢の初発例で あった。対称性のものは26例 $24 \%$ と少なく，その 中19例は球筇またはその他の筋の初発例で, 額㖪, 腰髄に始まる場合は非対称性, 延髄に始まる場合 は対称性分布が多いと考光られた。図14連続切 片，Nissl染色による第 6 頝䯣 $\left(\mathrm{C}_{6}\right)$ の $500 \mu \mathrm{m}$ ごと の左右の運動神経細胞数を示し，対照が注ぼ対称 性であるのに，同年令のALSは右側の細胞数が左 ょりも多く，非対称性で，臨床的な筋萎縮の非対 称性に対応した所見であった。

\section{3. その他の神経症候}

108例中深部反射亢進は81例75\%，ALS 95例で

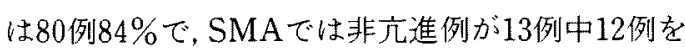
占めた。 Babinski徵候陽性は67例 $62 \%$, ALSでは 95 例中65例68\%, SMAでは 2 例15\%に陽性であっ た。表在覚低下 (12例), 疼痛 (11例), 異常覚 ( 5 例)などの感賞障害を 17 例 $16 \%$ ，眼振（ 7 例），眼

*本講演は1987年4月2日, 東京都港区芝公園 3-3-1, 東京プ日ンスホテルにて行なわれた。

Educational lecture on amyotrophic lateral sclerosis.

Hiroshi Tsukagoshr, Prof., Department of Neurology, Faculty of Medicine, Tokyo Medical and Dental University, Tokyo 


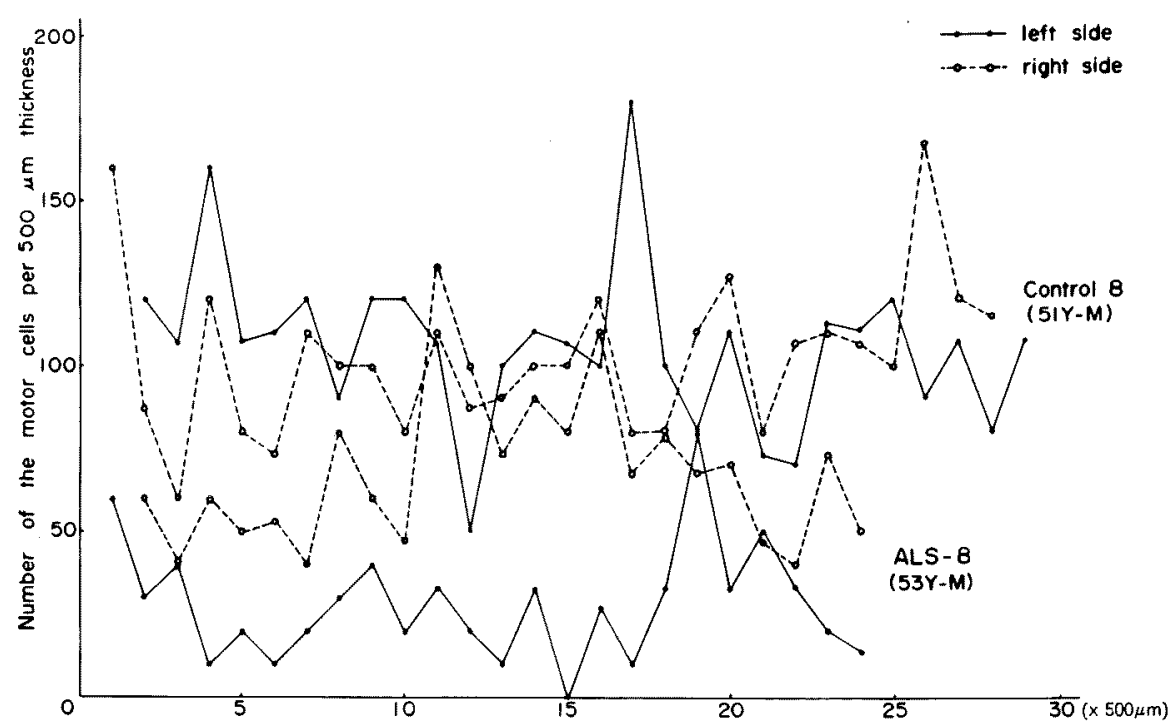

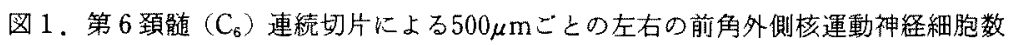
の分布。対照は左右ほ注対称性の分布を示すが，同年令のALSでは右側の運動細胞か゚ 左側よりも多く，場所によっては対照とほぼ同し所も西り，臨床的な筋萎縮の非対称 性に対応していた。

球運動障害 ( 5 例), 瞳孔異常など ( 4 例) の眼症 状を 16 例 $15 \%$ ，排尿困難（7 例），尿閉（2 例）， 尿失禁（1例）などの膀胱障害を10例 $9 \%$ に認め, 活かに固縮rigidityを 7 例 $7 \%$, 痴呆を 2 例 $2 \%$ に 認めた。感覚障害, 眼球運動障害, 膀胱障害はALS の陰性徵候とされるが，小数ではあるが陽性例の 存在は確かである。

\section{4. 特異な症例}

1) 異常覚と感覚低下を伴う例 ${ }^{11}$

患者は 53 才, 男, 主訴は呼吸困難, 筋萎縮と感 覚障害. 既往歴に26才の胸膜炎がある。現病歴は 43 才両下肢脱力, 45才左大駺部の痛久と異常覚が 出現, 徐々に上行した。 47 才東大神経内科入院. 両下肢の筋萎樎と深部反射亢進, Babinski徵候陽 性のほか斎以下の異常覚と感覚低下があった。入 院 1 カ月後異常覚と感覚低下は乳付近に達し, さ らに 3 力月後には両上肢の脱力之線維束孪縮, 感 賞低下も出現. 49才両足尖下垂, 51才曣下障害, 53才肺炎を起こし信州大第三内科で死亡した，顔 面筋, 舌 - 体幹・四肢筋に中等 高度の筋萎縮, 左顔面と頝部以下の表在覚低下があり, 深部反射
は消失していた，全経過10年．剖検では资䯣錐体 路之前根の変性, 前角細胞の脱落の汪か, 後根, 後根神経節細胞の変性を認め, 後索には著変なく, 後角のsubstance Pは同年令の対照と同様によく 保たれていた。

2）パーキンソニズムを伴い神経原線維変化を 認めた例 ${ }^{2}$

57才，男．主訴は頭部前屈と構語・嚥下障害。・ 既往歴：27才パラオ島に1力月滞在した。現病 歴: 50才歩行緩徐, 早口. 51才仮面様顔貌, 四 肢固緶からパーキンソニズムと診断された．53才

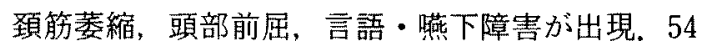
才全身がやせてきたが，固縮は軽快した，56才東 大第三内科入院. 顔面・舌 - 頚部 - 肩甲帯 -上腕 筋に筋萎縮之線維束挛縮があり, 言語は了解不能, 與下障害も強い, 手指の軽度振戦あり, 固縮, 感 覚障害はなく, 深部反射正常, Babinski徽候陰性, 57才, 食事中窒息で急死. 剖検で延髄, 资髄の運 動神経細胞と黒質の神経細胞脱落があるが，錐体 路障害はなく, 神経原線維変化をアンモン角, 視 床下核，黒質，動眼神経核，青斑核，偏桃核，縫 


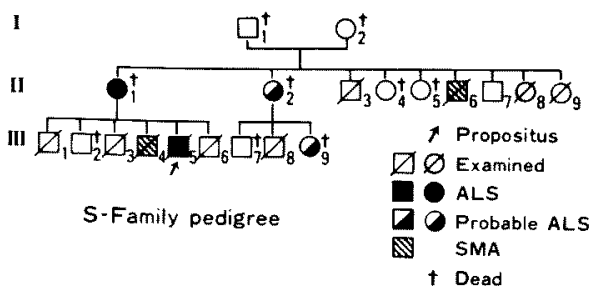

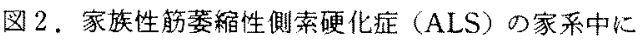

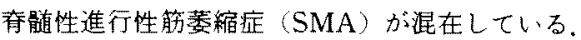

線核などに認め,グアム島の parkinsoismdementia and ALS complex 上同様な病理所見を 示した。

\section{5. 家族性ALS 4 家系 6 例の臨床と病理}

家族性ALS 4 家系 6 例は長野県南部の症例で, 臨床的に常染色体優性遺伝を示し，下肢筋初発で 仮性多発神経炎型を示さず，呼吸筋障害を起こし 易く，経過が比較的短かく，感覚障害はなく，同 一家系内䍜患者の類似性が強く，一家系では膀胱 障害を伴っていた，病理的には上位および下位運 動ニューロン障害のほか, 春噵後索と春髄小脳路 障害を全家系に認めた。

図 2 はこの中の特異な一家系"2で矢印の発端者 とその母, 叔母, 従弟にALS, 兄と叔父にSMAを 認めた。発端者は53才男。51才右足が上がり難く， 4 力月後階段の昇降が困難となり, 信州大第三内 科に入院．右下肢に中等度の筋萎樎と脱力，舌・ 上肢近位筋・肩甲带筋に線維束挛縮を認め，四肢 深部反射は正常一消失, Babinski徵候陰性, 筇電 図で上肢筇に多相性活動電位, 大腿四頭筋生検で angulated atrophic fiberを認めALSと診断され た。 1 年 2 カ月の経過で呼吸不全で死亡. 剖検で は春䯣錐体路の変性, 前角細胞の脱落, 资䯣前根 の大径有䯙線維减少のほか後索middle root zone と両側痏髄小脳路の变性, クラーク柱細胞の脱落 を認めた，発端者の兄は56才。小学生の頃から懸 垂, 腕立て伏せは苦手であった。40才頃から重い 物の挙上が困難となり，次第に増強した。両側三 角筋，上腕二頭筋・三頭筋に軽度の筋萎縮之脱力 を認め，右にやや優位で線維束挛維もあるが，体 幹・下肢笳は正常, 錐体路徵候はなく, 発症 17 年
後の現在も労働は可能で, SMA上診断された。発 端者の兄为 SMA と診断されており，同一家系内に ALSとSMAの共存する極めて交れな家系と考兄 られた。

\section{6. 疫学的所見，検查所見とALSの原因}

本症の疫学的所見拉よび娭查所見として，孤発 例と家族例の比が $102 ： 6$ ，男女比は67：49(1.6： 1) と孤発例, 男が多く，発症年令は20 29才 6 例 $(5.6 \%) ， 30 \sim 39$ 才 9 例 $(8.3 \%) ， 40 \sim 49 才 13$ 例 $(12.0 \%) ， 50 － 59 才 31$ 例 $(28.7 \%) ， 60 ６ 9 才$ 39 例 $(36.1 \%) ， 70$ 才以上 10 例 $(9.3 \%) \tau 50 \sim 69$ 才に多く，外傷また恃手術歴を65例(60.2\%)，ポ リ才後の発症を 2 例 $(1.9 \%)$ ，マクログロブリン 血症（11例），免疫グロブリン異常（3例），マイ クロゾーム・サイログロブリン試験陽性（6 例） などの免疫異常を 12 例（11.1\%）に，クレアチン カイネーズ $(\mathrm{CK})$ 上昇を79例中33例 $(41.8 \%) に$ ， 䯣液蛋白增加を88例中 30 例（34.1\%）に認めた。 これらの事夷から本症の原因として外因説，内分 泌異常説，加令，外傷，ポリオその他のウイルス との関連，免疫異常説，膜異常説などがだされ， このほか代謝異常，中毒など各種の原因が疑われ ているが，確定的なものはなく，原因はなお不明 である。

\section{7. 頚膸前角細胞数と断面積 初期変化との関連}

原因解明困難な理由の一つに，本症の初期变化 が不明な点が挙げられる。我々は䅡髄前角細胞の 初期变化について検討した. 正常対照11例(19～74 才）の第 6 頝䯣 $\left(\mathrm{C}_{6}\right)$ の連稅切片にNissl染色を行 ない，核小体のみ兄る前角運動神経細胞を最小径

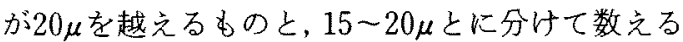
と, 表 1のよ5に大きい運動細胞は2000－37000, 小さい方は600〜1600であった. ALS 12例(35～68 才）について同様に数克ると（表 2 )，大きい運動 細胞は80 - 2400で，対照に比べ11例は有意に减少 し，小さい方の細胞は 4 例の文有意に減少して ALSでは大きい運動細胞が先に変化すると考兄 られだ!.

$\mathrm{C}_{6}$ およよび $\mathrm{C}_{8}$ の前角の顕微鏡写真を200倍に抎大 
表 1，正常対照の第 6 頝檤 $\left(\mathrm{C}_{6}\right)$ 前角外側 核運動神経細胞数

\begin{tabular}{|c|c|c|c|c|}
\hline \multicolumn{2}{|c|}{ 性と年令 } & \multirow{2}{*}{$\frac{\text { 左右 }}{\text { t5 }}$} & \multirow{2}{*}{$\begin{array}{c}\begin{array}{c}\text { 小徍運動稩胞 } \\
<15 \sim 20 \mu \leq\end{array} \\
1523\end{array}$} & \multirow{2}{*}{$\begin{array}{c}\begin{array}{c}\text { 大径運動細胞 } \\
20 \mu<\end{array} \\
3114\end{array}$} \\
\hline $19 才$ & 男 & & & \\
\hline & & 右 & 1339 & 3759 \\
\hline \multirow[t]{2}{*}{ 38才 } & 男 & 左 & 1181 & 3412 \\
\hline & & 右 & 1292 & 3508 \\
\hline $42 t$ & 男 & 左 & 705 & 2047 \\
\hline \multirow[t]{2}{*}{42 才 } & 男 & t & 1551 & 2143 \\
\hline & & 右 & 1447 & 2433 \\
\hline \multirow[t]{2}{*}{$47 \mathrm{~J}$} & 女 & 左 & 1631 & 2387 \\
\hline & & 右 & 1641 & 2904 \\
\hline \multirow[t]{2}{*}{$49 才$} & 女 & 左 & 640 & 2224 \\
\hline & & 右 & 656 & 2576 \\
\hline \multirow[t]{2}{*}{$51 t$} & 男 & 左 & 690 & 3070 \\
\hline & & 右 & 721 & 2959 \\
\hline 52 才 & 男 & 左 & 1232 & 2376 \\
\hline \multirow[t]{2}{*}{61 オ } & 男 & t도 & 1321 & 2238 \\
\hline & & 右 & 1230 & 2321 \\
\hline \multirow[t]{2}{*}{$69 才$} & 男 & 左 & 858 & 2279 \\
\hline & & 右 & 812 & 2006 \\
\hline 74才 & 男 & 左 & 1112 & 2184 \\
\hline
\end{tabular}

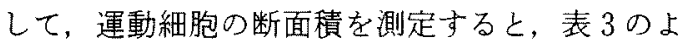
5 に対照12例（23～74才）の外側角，内側核細胞 の平均值と標準偏差に比へALS 20例（34～71才） の断面積は何れも有意の減少を示した。図 3 は $\mathrm{C}_{6}$ 外側核の運動細胞断面積の頻度分布で，対照12例 は900 $\mu \mathrm{m}^{2}$ 付近にピークのある対称性分布を示し， ALS 20 例は $400 \mu \mathrm{m}^{2}$ 付近にピークがあり，全体的 に断面積が小さくなっていた，図中の点柱は発症 後 1 年以内の死亡ALS 3 例の断面積で, 早期死亡 例でも残存運動細胞は小さいものが多く，日下， 平野いのいうようにALSの運動神経細胞は早期に 小さくなると考劣られた。

\section{8. 肺 機能}

ALSはをれに初期から呼吸障害をみることが あり，初期には肺機能正常でも中期以後には呼吸 障害が汪とんど必発する。本症の換気機能は32例 中正常 7 例 $(21.9 \%)$, 拘束性障害20例 $(62.5 \%)$, 混合性障害 5 例 (15.6\%) と拘束性障害が多かっ た。従って肺活量低下例が多かったが，これとそ の後の生存日数との関連は少なく，動脈血中炭酸 ガス分殴が50Torr以上を示すものは10日以内に 死亡した.

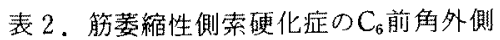
核運動神経細胞数

\begin{tabular}{|c|c|c|c|c|}
\hline \multicolumn{2}{|c|}{ 性と年命 } & \multirow{2}{*}{$\begin{array}{l}\text { 左右 } \\
\text { 左 }\end{array}$} & \multirow{2}{*}{$\begin{array}{c}\begin{array}{c}\text { 小徍通動細胞 } \\
<15 \sim 20 \mu \leqq\end{array} \\
176^{*}\end{array}$} & \multirow{2}{*}{$\begin{array}{c}\begin{array}{c}\text { 大径遇動紐胞 } \\
20 \mu<\end{array} \\
80^{*}\end{array}$} \\
\hline 60 才 & 男 & & & \\
\hline \multirow{2}{*}{\multicolumn{2}{|c|}{ 49才 女 }} & 左 & $375^{*}$ & $185^{*}$ \\
\hline & & 右 & $320^{*}$ & $200^{*}$ \\
\hline \multirow{2}{*}{\multicolumn{2}{|c|}{$61 t$}} & 左 & $338^{*}$ & $190^{*}$ \\
\hline & & 右 & 466 & $159^{*}$ \\
\hline \multirow{2}{*}{\multicolumn{2}{|c|}{$60 t$}} & 左 & $328^{*}$ & $176^{*}$ \\
\hline & & 右 & 408 & $225^{*}$ \\
\hline \multirow{2}{*}{\multicolumn{2}{|c|}{$42 才$}} & 左 & 888 & $408^{*}$ \\
\hline & & 右 & 920 & $464^{*}$ \\
\hline \multirow{2}{*}{\multicolumn{2}{|c|}{$68 t$}} & 左 & 666 & $544^{*}$ \\
\hline & & 右 & 632 & $544^{*}$ \\
\hline \multirow[t]{2}{*}{ 65才 } & 男 & 左 & 1680 & $850^{\circ}$ \\
\hline & & 右 & 1536 & $734^{\circ}$ \\
\hline \multirow{2}{*}{\multicolumn{2}{|c|}{$53 才$}} & 左 & 880 & $784^{*}$ \\
\hline & & 右 & 920 & 1680 \\
\hline \multirow[t]{2}{*}{ 53才 } & 男 & 左 & 992 & $856^{*}$ \\
\hline & & 右 & 1184 & $688^{\circ}$ \\
\hline \multirow[t]{2}{*}{$35 才$} & 女 & 左 & 2160 & $912^{*}$ \\
\hline & & $\hbar$ & 1840 & $896^{\circ}$ \\
\hline 56 才 & 女 & 左 & 1490 & $1039^{*}$ \\
\hline \multirow[t]{2}{*}{$63 才$} & 男 & 左 & 696 & 2401 \\
\hline & & 有 & 768 & 2271 \\
\hline
\end{tabular}

表 3。頸㭪前前角運動神経細胞断面積

\begin{tabular}{|c|c|c|c|c|}
\hline & \multicolumn{2}{|c|}{ 外側 } & 内 㑡 & 核 \\
\hline & $\mathrm{C}_{6}$ & $C_{B}$ & $C_{6}$ & $C_{8}$ \\
\hline 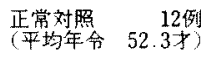 & $\begin{array}{r}939.23 \pm \\
343.75^{\circ}\end{array}$ & $\begin{array}{r}1071.59 \pm \\
386.17^{*}\end{array}$ & $\begin{array}{l}550.18 \pm \\
247.67\end{array}$ & $\begin{array}{r}634.80 \pm \\
244.61\end{array}$ \\
\hline $\begin{array}{lr}\text { ALS } & \begin{array}{l}20 \text { 例 } \\
\text { (平均年合 }\end{array} 55.9 \text { 才) }\end{array}$ & $\begin{array}{r}642.65 \pm \\
360.75\end{array}$ & $\begin{array}{l}670.34 \pm \\
363.78\end{array}$ & $\begin{array}{r}415.42 \pm \\
283.52\end{array}$ & $\begin{array}{r}348.91 \pm \\
166.38\end{array}$ \\
\hline $\begin{array}{l}\text { 対照とALS } \\
と \text { 有意差 }\end{array}$ & $p<0.001$ & $\mathrm{p}<0.001$ & $\mathrm{p}<0.05$ & $\mathrm{p}<0.001$ \\
\hline
\end{tabular}

神経細胞断面積：面積 $\left(\mu \mathrm{m}^{2}\right)$ の総和/神経細胞数(mean $\left.\pm \mathrm{SD}\right)$ ALS : 㳙萎樎性側索硬化症

* $\mathrm{p}<0.001$

\section{9. 予後とレスピレーター}

死亡日時の明らかな46例中発症後 1 年以内に 9 例 $19 \%, 3$ 年以内に 32 例 $67 \%, 5$ 年以内に 42 例 $88 \%$ が死亡し, ALS 45例の死亡までの期間は平均 29.7 月 2.5 年, SMAは 1 例死亡で18年ですった。初発部 位と死亡との関連は表 4 の上5に，上肢近位筋初 発例之仮性多発神経资型に $1 \sim 2$ 年以内の早期死 亡例が多く, 球麻痷型は予後が悪いとされている 

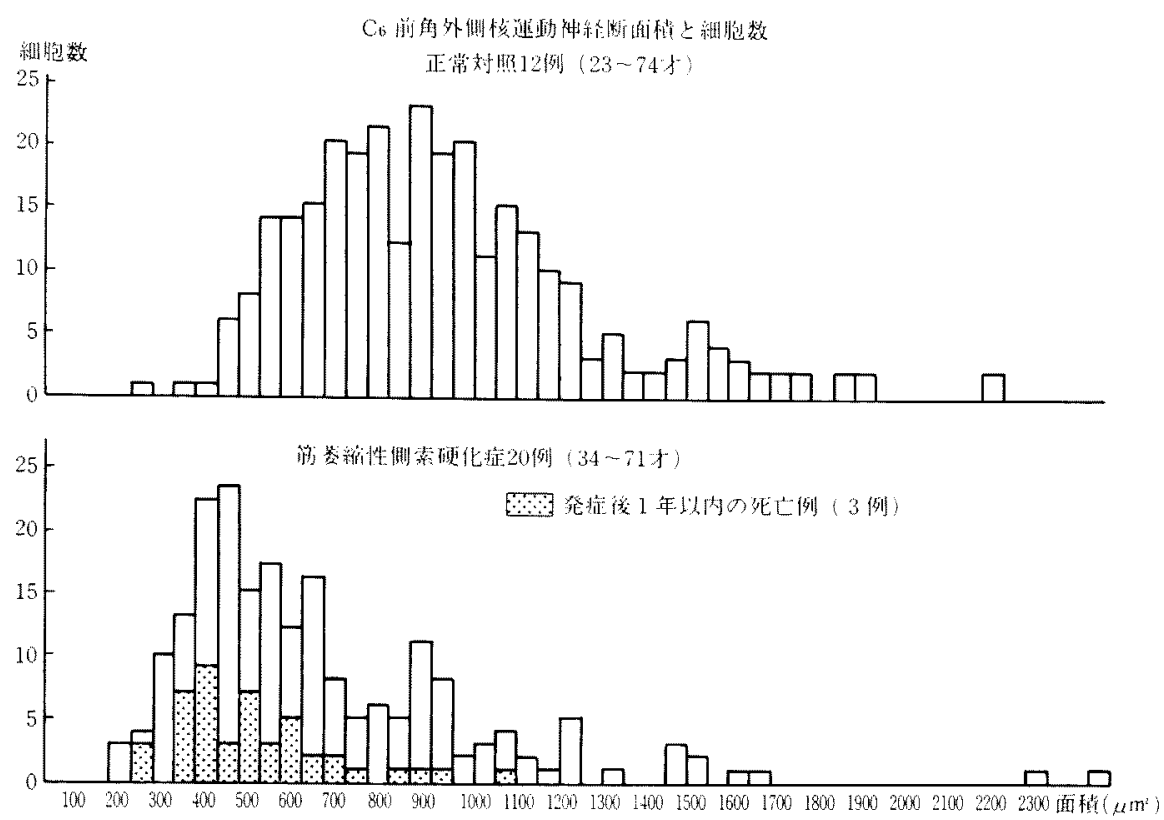

图 3．正常対照の前角外側核運動神経勫胞断面積は $900 \mu \mathrm{m}^{2}$ 付近にピークのあるほほ 対照性分布を示し，筋萎樎性側索硬化症は $450 \mu \mathrm{m}^{2}$ 付近にピークがあり，全体として運 動細胞断面積は小さくなっている，発症後 1 年以内に死亡した 3 例の残存運動神経細 胞断面皘も同様に小さいものが多い。

表 4. 初発部位と死亡までの期間

\begin{tabular}{|c|c|c|c|c|c|c|c|}
\hline \multirow{2}{*}{$\begin{array}{c}\text { 死亡までの } \\
\text { 期 間 }\end{array}$} & 上 & 䁌 & T & 肢 & \multirow[b]{2}{*}{ 球 筋 } & \multirow[b]{2}{*}{ その他 } & \multirow[b]{2}{*}{ 計 } \\
\hline & 遠位筋 & 近位荕 & $\begin{array}{l}\text { 㑐性多発 } \\
\text { 神経炎型 }\end{array}$ & $\begin{array}{l}\text { その地 } \\
\text { の胘 }\end{array}$ & & & \\
\hline 1 年 $\leqq$ & 0 & 2 & 4 & 1 & 2 & 0 & 9 \\
\hline$<1-2$ 年 $\leq$ & 3 & 2 & 2 & 4 & 1 & 0 & 12 \\
\hline$<2-3$ 年 $\leqq$ & 3 & 0 & 0 & 1 & 4 & 3 & 11 \\
\hline$<3-5$ 年 $\leqq$ & 3 & 0 & 1 & 1 & 4 & 1 & 10 \\
\hline$<5-10$ 年 $\leqq$ & 0 & 0 & 0 & 2 & 1 & 0 & 3 \\
\hline$<10 \sim 20$ 年 $\leqq$ & 0 & 1 & 0 & 0 & 0 & 0 & 1 \\
\hline 不 明 & 0 & 0 & 0 & 1 & 1 & 0 & 2 \\
\hline 計 & 9 & 5 & 7 & 10 & 13 & 4 & 48 \\
\hline
\end{tabular}

が，我々の例では早期死亡もあるが，3 年以上の 生存例も本れでなかった。 上肢遠位筋初発例は 1 〜 5 年の死亡が多く、これらの間には有意差を認 めた. ALS 45例の死亡までの期間は家族例 4 例 $19.8 \pm 13.6$ 月，孤発例 41 例 $30.7 \pm 22.3$ 月，男 29 例 $27.5 \pm 23.7$ 月，女16例 $33.8 \pm 17.7$ 月, $\mathrm{CK}$ 上昇 12 例
$24.8 \pm 13.9$ 月, CK正常22例31.7士26.8月と家族 例, 男，CK上昇例が短かかったが，これらの間に 有意差はなく, 発症年令と死亡迄の期間との間に も有意差はなかった。

レスピレーターをつけた 4 例は 8〜13力月平均 10力月の生命延長を認めた。これは死亡例につい てであり，現在レスピレーターをつけて 5 年以上 生存する例は变れでない、レスピレータ一装着に あたっては患者，家族と看護側との十分な話し合 いと了解を要する．今後は在宅でのレスピレー タ一使用を考慮すべきであろう。

\section{0. 進行停止例と治療}

本症の予後は不良であるが，まれに進行の停止 例をみることがある。最後の症例は51才の男。32 才に右下肢脱力，翌年左下肢脱力，34才杖歩行， 右手脱力, さらに左手脱力, 言語・與下障害の出 現により1973年（37才）信州大第三内科に入院. 上下肢の筋萎縮と線維束挛縮，深部反射六進， Babinski徵候陽性，筋電図所見からALS上診断， 
その後51才の現在までほとんど進行せず，2 本杖 歩行で日常生活動作は自立，話しは筆談が主であ るが，現在写植，ワープロの仕事をしている。

現在本症に有効な薬はなく，対症療法が主と なっている。最近TRHの大量投与が有効と言われ たが，病気の進行を阻止できないことが明らかに なった。しかし進行の自然停止例やALS家系中に SMAをみることは, 本症の進行を阻止し得る可能 性を考学させるのであり，難病中の難病とされる 本症の原因解明，治療法探求の努力を続ける必要 性を痛感する。

\section{文献}

1)馬目太三，他：著名な異常感竟と表在感覚鈍麻を 示した笳萎䧽性側索硬化症の剖模例。臨床神経学 $20: 225,1980$.

2) 中野 武, 他：同一家系内に筋萎樎性側索硬化应

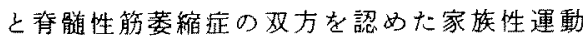
=ューロン疾患の1家系. 臨床神経学 25:1119 1986.

3) Tsukagoshi $H$, et al: Morphometric quantification of the cervical limb motor cells in controls and in amyotrophic lateral sclerosis J Neurol Sci $41: 287,1979$.

4) 日下博文，平野朝雄：筋萎綰性側索硬化症に打け る「正常」残存細胞の㛟討。神経内科 $22: 359$, 1985. 